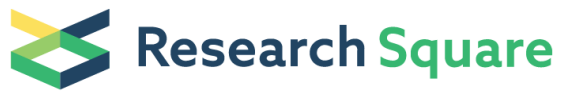 \\ Preprints are preliminary reports that have not undergone peer review. \\ They should not be considered conclusive, used to inform clinical practice, \\ or referenced by the media as validated information.
}

\section{Retrospective Cohort Study of Neonatal Blood Transfusion in China}

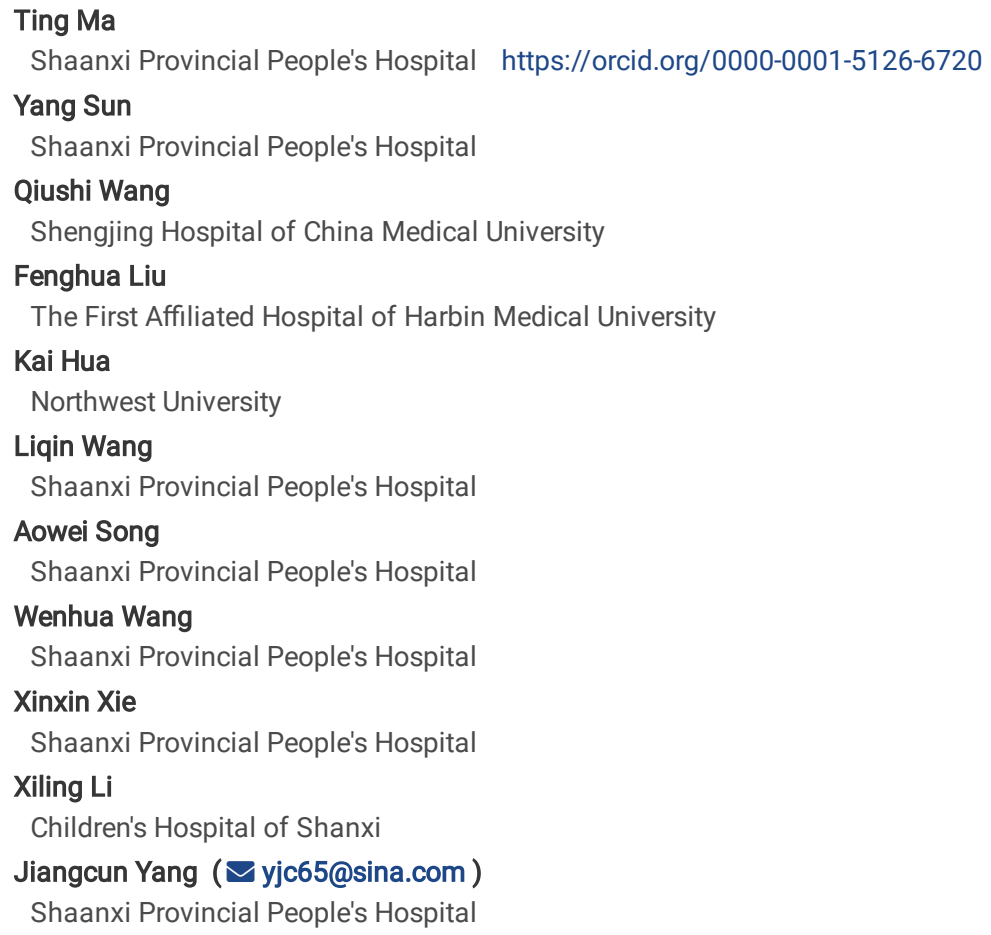




\section{Abstract}

Background: Blood transfusion treatment is extremely important for newborns $\llbracket$ but the threshold of neonatal blood transfusion is not same in different countries, which may be due to differences in regions, races and nationalities, as well as medical conditions and treatment methods. Up to now, there are not enough clinical studies and prospective follow-up to determine the suitable threshold for Chinese newborns. Therefore, it is important to establish a retrospective and prospective multicenter cohort study to evaluate whether the blood transfusion scheme is suitable for newborns in China.

Methods: This is a retrospective cohort study of neonatal blood transfusion and prospective follow-up from January 1, 2017 to June 30, 2021, aim to evaluate the effect of restricted and unrestricted blood transfusion on neonatal health. Diagnosis and blood transfusion data of 5,669 newborns between January 1 , 2017 and June 30, 2018 from 46 hospitals in China were analyzed through retrospective study and followed up for $1 \mathrm{w}, 1 \mathrm{~m}$ and $3 \mathrm{y}$ after discharge. The variable data of newborns and their mothers was collected in this cohort study with 280 variables and 2.98 million data volumes including in the database. The primary outcome index of the study was death, and the secondary outcome index was complications during hospitalization, hospitalization time, NICU hospitalization days and hospitalization expenses.

Discussion: The groups were grouped by birth weight, and each group was defined as a restricted and unrestricted cohort according to the Recommended Program for Neonatal Blood Transfusion (5th Edition), and evaluate applicability of this scheme for Chinese newborns based on outcome indicators. According to the neonatal treatment data, a appropriate neonatal blood transfusion threshold and neonatal blood transfusion program for China would be determined.

\section{Contributions To The Literature}

- This is a retrospective cohort study of neonatal blood transfusion and prospective follow-up from January 1, 2017 to June 30, 2021, aim to evaluate the effect of restricted and unrestricted blood transfusion on neonatal health.

- The variable data of newborns and their mothers was collected in this cohort study with 280 variables and 2.98 million data volumes including in the database. The primary outcome index of the study was death.

- The mortality rate of restricted blood transfusion in $<1500 \mathrm{~g}$ group was significantly higher than that in the non-restricted blood transfusion group. The threshold of this group was not applicable to Chinese newborns. The mortality rate of restricted blood transfusion in $>2500 \mathrm{~g}$ group is lower than that in the non-restricted blood transfusion group. This threshold treatment scheme shows great valuable in newborn protection and will be verified in combination with long-term effects.

\section{Background}

Neonatal blood transfusion is used for treatment of neonatal anemia caused by various reasons, neonatal thrombocytopenia and coagulation dysfunction related diseases. Newborns, a special group, have imperfect hematopoietic system and rapid disease changes. Blood transfusion treatment is extremely important for newborns, especial very low birth who suffer undeveloped hematopoietic system and rapid disease changes. with blood transfusion rate as high as over $80 \%$ during hospitalization ${ }^{[1-5]}$. And gestational age is inversely proportional to the number of blood transfusions ${ }^{[6]}$. However, improper blood transfusion treatment also brings risks. For example, excessive blood transfusion can lead to iron load, heavy circulatory load, intraventricular hemorrhage and adverse reactions of blood transfusion ${ }^{[7-11]}$. Insufficient blood transfusion treatment will affect neonatal development and therapeutic effect disease treatment, and could lead to apnea, neurodysplasia or poor weight gain ${ }^{[12]}$. Therefore, it is extremely important to determine the threshold of neonatal blood transfusion treatment. The research results show that a small group of countries including Britain, the United States and Australia have formulated neonatal blood transfusion programs ${ }^{[6,13-15]}$, but the threshold of neonatal blood transfusion is not same in different countries, which may be due to differences in regions, races and nationalities, as well as medical conditions and treatment methods ${ }^{[16]}$. The neonatal blood transfusion program standardized the protocol of neonatal blood transfusion treatment, but it also brings hidden dangers. Especially for VLBW infants, a large number of studies have reported that strict blood transfusion threshold will increase the incidence of severe neurology in newborns, reduce long-term brain volume, increase the incidence of periventricular leukomalacia and a series of complications of intraventricular hemorrhage ${ }^{[17]}$. At present, doctors in China is still relying on clinical experience or referring to foreign programs for treatment. The recommended threshold for neonatal blood transfusion treatment in China is still from the fifth edition of Practical Neonatology. Up to now, there are not enough clinical studies and prospective follow-up to determine the suitable threshold for Chinese newborns. Therefore, it is important to establish a retrospective and prospective multicenter cohort study to evaluate whether the blood transfusion scheme is suitable for newborns in China.

It has been reported that different blood transfusion thresholds should be adopted for newborns with different weights, and a higher threshold should be carried out in unrestricted blood transfusion for newborns with very low weights, so as to ensure the development of their nervous system. More and more studies showed that the adverse effects of restricted blood transfusion on newborns have inconsistent results, especially for low birth weight infants and newborns with severe disease ${ }^{[18-22]}$. In addition, due to the physiological decline of hemoglobin level of newborns after birth, it is more difficult to judge physiological anemia or pathological anemia of newborns ${ }^{[23]}$. There are many factors should be taken into consideration in newborns' blood transfusion, especially for low birth weight infants, including disease type, weight, assisted breathing mode, gestational age at birth, clinical signs, threshold of blood transfusion treatment, blood transfusion volume and selection of blood products and so on. Previous cohort studies were carried out in other countries and regions with fewer observation variables and smaller sample size, which only reflected the local neonatal blood transfusion and prognosis. The indicators involved in reflecting the variables within the group are not comprehensive enough. Most of the studies focus on the threshold of blood transfusion treatment, the occurrence of adverse reactions of blood transfusion and growth and development. Previous investigations barely include infusion volume and blood products for newborns in cohort studies. It has been reported that the total amount of blood infused in low birth weight infants is related to necrotizing

Page 2/12 
enterocolitis(NEC) associated blood transfusion. Infants within 32 weeks or with a weight lower than $1500 \mathrm{~g}$ have been recommended to take blood transfusion on $15 \mathrm{ml} / \mathrm{kg}$ volume instead of calculating with traditional formula ${ }^{[10]}$. Some researchers believe that using irradiated red blood cells for VLBW newborns can reduce the occurrence of transfusion-related graft host disease (TA-GVHD), but a large amount of irradiated red blood cells could increase the risk of hyperkalemia ${ }^{[24,25]}$. The use of washed red blood cells and less white red blood cells has been taken into consideration as well, which might be beneficial in reducing anticoagulant-preservative exposure and cytomegalovirus infection in newborns ${ }^{[26,27]}$. Therefore, it is necessary to establish a multicenter cohort study in China with variables comprehensively reflect the individual blood transfusion treatment and long-term effects of newborns in order to establish a neonatal blood transfusion program suitable for China.

So far, there is no cohort study of neonatal blood transfusion programs in China. In order to fill this gap, we established a multicenter retrospective and prospective study cohort to observe the treatment status, clinical symptoms, signs and other variables of transfused newborns during hospital, and prospective follow-up for 1 week, 1 month and 3 years after discharge. The cohort involves 5,669 newborns with blood transfusion from 46 hospitals in China of 7 regions and 21 provinces, each case contained 280 variables, with a total of 2.98 million variables. The main objective of this cohort study include, 1) To determine the downward trend of hemoglobin level in hospitalized newborns with time and the physiological changes of neonatal hemoglobin, 2) The groups were grouped by birth weight, and each group was defined as a restricted and unrestricted cohort according to the Recommended Program for Neonatal Blood Transfusion (5th Edition), and evaluate applicability of this scheme for Chinese newborns based on outcome indicators, 3) According to the neonatal treatment data, a appropriate neonatal blood transfusion threshold and neonatal blood transfusion program for China would be determined. This study was approved by the Ethics Committee of the Institutional Evaluation Committee of Shaanxi Provincial People's Hospital (NO: 2020-R001).

\section{Methods}

\section{Who is in the cohort?}

In this study, the neonatal blood transfusion cohort was established to provide evidence-based medical basis for formulating the treatment plan or guideline of neonatal blood transfusion in China. The diagnosis and treatment data of inpatients with blood transfusion was from 46 hospitals in 21 provinces of China. A multi-center retrospective and prospective study method was carried out to systematically investigate the blood transfusion of newborns in China.

A unified spreadsheet was used to collect data in Forty-six hospitals covering 21 provinces and cities (Beijing, Gansu, Guangdong, Guangxi, Guizhou, Hebei, Henan, Heilongjiang, Hubei, Jilin, Jiangxi, Liaoning, Inner Mongolia, Shandong, Shanxi, Shaanxi, Sichuan, Xinjiang, Yunnan, Zhejiang, Chongqing, shown in Fig. 1). The data spreadsheet is unified and integrated in Shaanxi Provincial People's Hospital, the responsible unit of this project, for unified collation and analysis. The database included 5669 hospitalized newborns with blood transfusion from January 2017 to June 2018 . There are 280 variables in each case, including newborn mother information and newborn blood transfusion treatment information, The maternal variables include the address where the child's mother is located, hospital, age, delivery mode, multiple births, pregnancy times, parity times, and maternal complications. The neonatal variables include the baseline data of the child: gender, date of birth, date of admission, date of discharge, birth weight, birth length, birth head circumference, admission weight, Agpar score (1-5-10), and newborn admission-associated diseases (15 kinds); Blood test indexes: newborn blood type, routine blood indexes (10 test points), liver function indexes ( 5 test points), coagulation indexes ( 5 test points) and blood gas indexes (10 test points); Treatment and observation indicators: surgical operation (8 kinds), delivery room resuscitation methods (9 kinds), ventilator application (3 kinds), postpartum umbilical cord clamping time, blood transfusion treatment, infusion time, infusion volume, blood transfusion products (10 kinds of blood products), blood transfusion adverse events ( 8 kinds), clinical manifestations after blood transfusion (4 directions), iatrogenic blood loss evaluation $(<1500 \mathrm{~g})$, exchange transfusion treatment, exchange transfusion components, exchange transfusion volume, exchange transfusion blood type; Outcome indicators: discharge weight, hospitalization days (days), hospitalization expenses (yuan), stay in NICU days (days), main diagnosis of discharge (14 kinds), outcome of children (cure and improvement, transfer to hospital, death), complications during hospitalization (12 kinds), causes of death (9 kinds), discharge follow-up (1W/1M) and Bailey Infant Development Scale evaluation at 3 years old ${ }^{[28]}$. The Bailey Scale is divided into three scales: 1) Intelligence Scale (163 items) 2) Exercise Scale (81 items) 3 ) Social Behavior. (Table 1)

Among 5669 newborns with blood transfusion, 625 newborns with exchange transfusion treatment, 848 newborns with simple plasma transfusion, 43 newborns with simple platelet transfusion, 22 newborns with simultaneous platelet and plasma transfusion and 210 newborns with incomplete data were excluded, and 1.8 million data of 3921 newborns with red blood cell transfusion were analyzed (shown in Fig. 2).

In this cohort study, 3921 newborns infused with red blood cells were divided into three groups according to their birth weight, namely < $1500 \mathrm{~g}, 1500-2500 \mathrm{~g}$, and $\geq 2500 \mathrm{~g}$. Transfusion intervention was performed according to the threshold of neonatal blood transfusion in the fifth edition of Practical Neonatology among each group, and the $\mathrm{Hb}$ value of newborns before the first blood transfusion was detected. The $\mathrm{Hb}$ lower than the threshold was defined as restricted blood transfusion group, and the $\mathrm{Hb}$ higher than the threshold was defined as non-restricted blood transfusion group. Therefore, we established three groups of neonatal blood transfusion cohorts by different weights.

We established a retrospective cohort of 3,921 neonates with red blood cell transfusion from January 1, 2017 to June 30,2018 with 1.8 million valid data. This cohort is a relatively large neonatal blood transfusion cohort, and the newborns in this cohort are followed up after discharge and prospectively expanded.

\section{Blood sampling}

Among the 280 variables observed, we collected 5 blood transfusion time points and transfusion methods, and included more blood index detection points, so as to evaluate the blood transfusion effect in time and effectively. Blood samples are collected and tested according to strict guidelines. Blood routine index test has been taken with 10 results after admission. Liver function test and coagulation function test indexes were included in the results of 5 tests after 
admission. The indexes of blood gas test were included in the results of 10 times after admission. If the detection time point of the neonate is less than the set number of times, all results are included.

\section{Sub-studies collecting clinical data}

Among the 5,669 cases, 3,921 cases of red blood cell infusion were used for cohort study. The other 625 newborn exchange transfusion cases were included in a sub-research project to explore appropriate exchange transfusion treatment schemes. The information of clinical medication was included in this subproject research, such as blue light therapy, phenytoin sodium and albumin use. The plasma transfusion group of 1677 cases include plasma transfusion alone, simultaneous plasma and red blood cell transfusion, and simultaneous plasma and platelet transfusion, which will further explore for clinical application scheme of plasma in this sub-project study.

\section{How often have they been followed up?}

Since the neonatal blood transfusion database has been established in 2017, 5,669 cases were included. New records of 280 variables were updated after hospital discharge, and cohorts were established according to weights and recommended thresholds for newborns. The first statistical analysis of data will include the variables during hospitalization and the follow-up results of 1 week and 1 month after discharge, i.e. The retrospective follow-up time lasted until July 30, 2018. The survival of all newborns was followed up from 1 week to 1 month after discharge. After that, all cases were followed up for 3 years, and the long-term effects on growth and development were evaluated by Bailey Scale. Cohort participants were considered reaching their follow-up endpoints if they satisfied one of the following: 1) individual death of newborns; 2) Newborns lost follow-up within 3 years of age.

\section{Discussion}

In the three cohorts with different weights, the distribution of mothers' baseline age, delivery mode, multiple births, parity, pregnancy times and accompanying complications is basically the same (Table 2), which reflects the matching choice of baseline characteristics of newborn mothers. The baseline characteristics of newborns in the three groups are basically the same in sex, birth weight, birth length, birth head circumference, admission weight, Agpar score, and the number of concomitant diseases. The < $1500 \mathrm{~g}$ group has differences in Agpar score $5 \mathrm{~min}, 10 \mathrm{~min}$ and ventilator use. There are differences in gender, birth length, admission weight and ventilator use in the 1500-2500 g group. The birth weight, Agpar score and ventilator use were different in the $\geq 2500 \mathrm{~g}$ group. This reflects the matching selection of neonatal baseline characteristics (Table 3).

The investigation of blood transfusion treatment in $<1500 \mathrm{~g}$ group showed that compared with the non-restrictive transfusion group, the restrictive transfusion group had lower levels of $\mathrm{Hb}$ at the time of admission and hospitalization. The number of infusions and the average total infusion volume were larger in the restricted transfusion group, but the average infusion volume per infusion was the same between the two groups (Table 4). Among the secondary outcome indicators, the restricted transfusion group had fewer costs. The main outcome indicators showed that there was a statistical difference between the two groups. The implementation of this standard significantly increases the risk of death. The mortality rate in restricted infusion group (11.41\%) was higher than that in non-restricted infusion group (5.12\%). According to the analysis of treatment, secondary outcome indicators and death, the threshold of $<1500 \mathrm{~g}$ neonatal blood transfusion scheme is not suitable to Chinese neonatal population, and a better blood transfusion scheme should be established in combination with the long-term effect evaluation results (Table 5,6).

The study of blood transfusion treatment in the 1500-2500g group suggested that compared with non-restrictive transfusion group, restrictive transfusion group had lower levels of $\mathrm{Hb}$ at the time of admission, hospitalization and discharge. There was no difference in other blood transfusion treatments between the two groups. Among the secondary outcome indicators, the restricted transfusion group had fewer hospitalization time, NICU time, and hospital costs, and there was no difference in complications during hospitalization between the two groups. The mortality rate of restricted infusion group (3.53) was lower than that of unrestricted infusion group (4.71)(Table 5,6), but there was still no statistical significance between the two groups. According to the above results, it is also necessary to further explore a more ideal blood transfusion scheme.

Blood transfusion treatment in $\geq 2500 \mathrm{~g}$ group suggest that compared with non-restrictive transfusion group, restrictive transfusion group had lower levels of $\mathrm{Hb}$ at the time of admission, hospitalization and discharge. There was no significant difference between the two groups in the treatment methods of transfusion of red blood cells, plasma and platelets. Among the secondary outcome indicators, the restricted transfusion group had fewer hospitalization time and hospital costs. The death outcome of the two groups showed that the mortality rate of restricted infusion group (3.02) was significantly lower than that of non-restricted infusion group (9.55)(Table 5,6). Combined with the above analysis results, the blood transfusion threshold adopted by this group is a more appropriate blood transfusion scheme, and then the results should be verified with the long-term effect results.

\section{What are the main strengths and weaknesses?}

The establishment of neonatal blood transfusion cohort in China has important implications. First of all, this is the first neonatal blood transfusion cohort study established in China. At present, China's neonatal blood transfusion guidelines still fellow foreign blood transfusion guidelines, so there is no research report on the neonatal blood transfusion threshold in this country. The cohort includes neonatal blood transfusion cases from 46 hospitals in 21 provinces and cities in China, which can provide representative characteristics of the Chinese neonatal population. Secondly, newborns are a special group with complex and changeable diseases. The cohort established in this study covers 280 variable data, which is the study with the largest number of variables known in the world. It includes the baseline data of both mother and newborn, all the information of newborn blood transfusion treatment, as well as the main treatment methods and comprehensive laboratory indicators during hospitalization. The database enables a comprehensive observation of newborns. It provides a reliable data in determine the best blood transfusion threshold of newborns. Third, the data is large in volume. According to the birth weights of newborns, 
three groups of neonatal blood transfusion cohorts were established. Fourthly, the end point of the cohort was 3-year-old newborns, and the Bailey scale was used to evaluate the long-term effect of blood transfusion on their growth and development.

This cohort study has some limitations. First, the cohort is based on retrospective data, so there are differences in the amount of cases and baseline data between restricted blood transfusion group and unrestricted blood transfusion group. Secondly, the observation outcome index in this paper only includes the follow-up study of 1 week and 1 month after discharge, and the real endpoint is the long-term effect evaluation table from prospective to 3-year-old exit, so only preliminary observation results are obtained. Thirdly, due to the different on the geographical location and economic situation, party of data was lost in the final export, but the large sample in this study could make up partly. An adjustment will be made in the inappropriate blood transfusion scheme and establish a blood transfusion threshold scheme that meets the needs of Chinese newborns.

\section{Abbreviations}

VLBW : very low birth weight

NEC : necrotizing enterocolitis

TA-GVHD : transfusion-related graft host disease

\section{Declarations}

\section{Ethical Approval and Consent to participate}

Ethical approval for the study was obtained from the institutional review board of People's Hospital of Shaanxi Province (No: 2020-R001)

\section{Consent for publication}

Not applicable

\section{Availability of data and materials}

We warmly welcome the cooperation for the cohort study of neonatal blood transfusion in China and make full use of the data. Since the research is still undergoing and the information used in this study relate to personal privacy, the database cannot be open in the public domain for free, but researchers interested in collaboration and further information are welcome to contact the corresponding authors via email [yjc65@sina.com].

Competing interests: The authors declare that they have no conflicts of interest relevant to the manuscript submitted to Implementation Science.

Funding : This work was part of the Program on Shaanxi province scientific and technological achievements transfer and promotion project $₫$ grant number 2019CGHJ-09.

\section{Authorship contributions}

Conceptualization: Yang Jiangcun

Data curation: Ma Ting, Sun Yang

Formal analysis: Wang Qiushi , Li Xiling®Liu Fenghua,

Investigation: Wang Qiushi , Li Xiling, Song Aowei, Wang Wenhua, Xie Xinxin,

Methodology: Liu Fenghua, Wang Liqin

Writing - original draft: Ma Ting, Sun Yang, Hua Kai

Writing - review \& editing: Yang Jiangcun, Ma Ting

\section{Acknowledgments}

Thanks to the following people of 46 hospitals for their contributions to this article, in no particular order.

Anyan Deng.BS, Chong Zhang.PhD, Danni Zhong.PhD, Dong Zhou.PhD, Fang Han.PhD, Fang Liu.PhD, Feng Chen.MD, Fenghua Liu.BS, Hailan Li.BS, Hasitana.MD, Heqin Li.BS, Hongbing Hu.MD, Hua Mei.MD, Huiqing Sun.PhD, Jianchun Lv.BS, Jiang Xue.MD, Jie Xiao.MD, Juan Wang.MD, Kexuan Qu.MD, Lijun Mei.BS, Lingli Miao.BS, Long Chen.PhD, Long Li.BS, Maoqiong Chen.MD, Ping Zheng.BS, Qian Hou.BS, Qiang Feng.BS, Qin Lv.MD, Qiuju Liu.PhD, Rongxuan Wei.MD, Ru Lin.MD, Shengchao Jin.PhD, Shuping Dai.MD, Shurong Li.BS, Sihua Yi.PhD, Tao Peng.PhD, Tianhua Jiang.BS, Wen Yin.PhD, Xiao Zhang.MD, Xiaoliang Zeng.BS, Xiling Li.BS, Xuezhen Song.BS, Xun Jiang.PhD, Yang yu.PhD, Yi Wei.PhD,Yingying Guo.MD, Yuanshuai Huang.PhD, Zhenai Jin. $\mathrm{PhD}$

\section{Authors' information}

a Department of Transfusion Medicine, Shaanxi Provincial People's Hospital, Xi'an 710068, China 
b Department of Data Center, Shaanxi Provincial People's Hospital, Xi'an 710068, China

c Department of Transfusion Medicine, Shengjing Hospital of China Medical University, Shenyang 110004, China

d Department of Transfusion Medicine,The Fisrt Affiliated Hospital of Harbin Medical University, Harbin 150000, China

e College of life sciences, Northwest University, Xi'an 710068, China

f Department of Transfusion Medicine, Children's Hospital of ShanXi, Taiyuan 030013, China

\section{References}

1. Strauss RG. Anaemia of Prematurity: Pathophysiology \& Treatment[J]. Blood Rev. 2010;24(6):221-5.

2. Banerjee J, Asamoah FK, Singhvi D, Kwan AWG, Morris JK, Aladangady N. Haemoglobin level at birth is associated with short term outcomes and mortality in preterm infants[J]. Bmc Medicine. 2015;13(1):16-22.

3. Keir AK, Yang J, Harrison A, Pelausa E, Shah PS. Temporal changes in blood product usage in preterm neonates born at less than 30 weeks' gestation in Canada[J]. Transfusion. 2015;55(6):1340-6.

4. Ghirardello S, Dusi E, Cortinovis I, Villa S, Fumagalli M, Agosti M, Milani S, Mosca F. Effects of Red Blood Cell Transfusions on the Risk of Developing Complications or Death: An Observational Study of a Cohort of Very Low Birth Weight Infants[J]. Amer J Perinatol. 2017;34(1):88-95.

5. Villeneuve A, Lapointe A, Lachance C, Ducruet T, Lacroix J. Epidemiology and Determinants of Transfusions of Red Blood Cells, Plasma and Platelet Concentrates in a Neonatal Intensive Care Unit (NICU): A Single Center Cohort Study[J]. Paediatrics \& Child Health, 2014(6):e58-e58.

6. Strauss. RBC transfusion and/or recombinant EPO therapy of the anaemia of prematurity[J]. Isbt Science. 2010;1(1):11-4.

7. Baer VL, Lambert DK, Henry E, Snow GL, Christensen RD. Red blood cell transfusion of preterm neonates with a Grade 1 intraventricular hemorrhage is associated with extension to a Grade 3 or 4 hemorrhage. Transfusion. 2011;51(9):1933-9.

8. Hirano K, Morinobu T, Kim H, Hiroi M, Ban R, Ogawa S, Ogihara H, Tamai H, Ogihara T. Blood transfusion increases radical promoting non-transferrin bound iron in preterm infants. Arch Dis Child Fetal Neonatal Ed. 2001;84(3):F188-93.

9. Ng PC, Lam CW, Lee CH, To KF, Fok TF, Chan IH, Wong E. Hepatic iron storage in very low birthweight infants after multiple blood transfusions. Arch Dis Child Fetal Neonatal Ed. 2001;84(2):F101-5.

10. Marin T, Moore J, Kosmetatos N, Roback JD, Weiss P, Higgins M, McCauley L, Strickland OL, Josephson CD. Red blood cell transfusion-related necrotizing enterocolitis in very-low-birthweight infants: a near-infrared spectroscopy investigation. Transfusion. 2013;53(11):2650-8.

11. Josephson CD, Wesolowski A, Bao G, Sola-Visner MC, Dudell G, Castillejo MI, Shaz BH, Easley KA, Hillyer CD, Maheshwari A. Do Red Cell Transfusions Increase the Risk of Necrotizing Enterocolitis in Premature Infants?[J]. J Pediatr. 2010;157(6):972-8.

12. Stockman JA, Clark DA. Weight Gain: A Response to Transfusion in Selected Preterm Infants[J]. Am J Dis Child. 1984;138(9):828-30.

13. English Al. Red blood cell transfusions in newborn infants: Revised guidelines[J]. Paediatrics Child Health. 2002;7(8):553-66.

14. Gibson BE, Todd A, Roberts I, Pamphilon D, Rodeck C, Bolton-Maggs P, Burbin G, Duguid J, Boulton F, Cohen H, Smith N, McClelland DB, Rowley M, Turner G. British Commitee for Standards in Haematology Transfusion Task Force: Writing group. Transfusion guidelines for neonates and older children[J]. Br J Haematol. 2004;124(4):433.

15. Girelli G, Antoncecchi S, Casadei AM, Del Vecchio A, Isernia P, Motta M, Regoli D, Romagnoli C, Tripodi G, Velati C. Recommendations for transfusion therapy in neonatology. Blood Transfus. 2015;13(3):484-97.

16. von Lindern JS, Lopriore E. Management and prevention of neonatal anemia: current evidence and guidelines. Expert Rev Hematol. 2014;7(2):195-202.

17. Bell EF, Strauss RG, Widness JA, Mahoney LT, Mock DM, Seward VJ, Cress GA, Johnson KJ, Kromer IJ, Zimmerman MB. Randomized Trial of Liberal Versus Restrictive Guidelines for Red Blood Cell Transfusion in Preterm Infants[J]. Pediatrics, 115(6):1685-91.

18. Demirel G, Celik IH, Aksoy HT, Erdeve O, Oguz SS, Uras N, Dilmen U. Transfusion-associated necrotising enterocolitis in very low birth weight premature infants. Transfus Med. 2012;22(5):332-7.

19. Faraday C, Hamad S, Jones KD, Sim K, Cherian S, James A, Godambe S, New HV, Kroll JS, Clarke P. Characteristics and incidence of transfusionassociated necrotizing enterocolitis in the UK. J Matern Fetal Neonatal Med. 2020;33(3):398-403.

20. Kirpalani H, Whyte RK, Andersen C, Asztalos EV, Heddle N, Blajchman MA, Peliowski A, Rios A, LaCorte M, Connelly R, Barrington K, Roberts RS. The Premature Infants in Need of Transfusion (PINT) study: a randomized, controlled trial of a restrictive (low) versus liberal (high) transfusion threshold for extremely low birth weight infants. J Pediatr. 2006;149(3):301-7.

21. Lust C, Vesoulis Z, Jackups R, Jr,Liao S, Rao R, Mathur AM. Early red cell transfusion is associated with development of severe retinopathy of prematurity. J Perinatol. 2019;39(3):393-400.

22. Rashid N, Al-Sufayan F, Seshia MM, Baier RJ. Post transfusion lung injury in the neonatal population. J Perinatol. 2013;33(4):292-6.

23. Lau W. Publishers Internet. Neonatal and Pediatric Transfusion: Clinical Guide to Transfusion. Canadian Blood Services cited 2017. Available from https://professionaleducation.blood.ca/en/neonatal-and-pediatric-transfusion.

24. Winter KM, Johnson L, Kwok M, Reid S, Alarimi Z, Wong JK, Dennington PM, Marks DC. Understanding the effects of gamma-irradiation on potassium levels in red cell concentrates stored in SAG-M for neonatal red cell transfusion. Vox Sang. 2015;108(2):141-50.

25. Favrais G, Wibaut B, Pladys P, Saliba E. [Blood transfusion to pre-term neonates: What is new in the French guidelines since 2002?][J]. Arch Pediatr. 2017;24(9):894-901. 
26. Keir AK, Wilkinson D, Andersen C, Stark MJ. Washed versus unwashed red blood cells for transfusion for the prevention of morbidity and mortality in preterm infants[J]. Cochrane Database of Systematic Reviews. 2016;1(1):CD011484.

27. Seed CR, Wong J, Polizzotto MN, Faddy H, Keller AJ, Pinket J. The residual risk of transfusion-transmitted cytomegalovirus infection associated with leucodepleted blood components[J]. Vox Sang. 2015;109(1):11-7.

28. Whyte RK, Kirpalani H, Asztalos EV, Andersen C, Blajchman M, Heddle N, LaCorte M, Robertson CM, Clarke MC, Vincer MJ, Doyle LW, Roberts RS, PINTOS Study Group. Neurodevelopmental outcome of extremely low birth weight infants randomly assigned to restrictive or liberal hemoglobin thresholds for blood transfusion. Pediatrics. 2009;123(1):207-13.

\section{Tables}

Table 1 Data collection of neonatal blood transfusion cohort: variables of neonatal mother and neonatal groups

\begin{tabular}{|c|c|c|c|c|}
\hline \multirow[t]{2}{*}{ Mother variable } & \multicolumn{4}{|l|}{ Neonatal variable } \\
\hline & Baseline & Blood test index & $\begin{array}{l}\text { Treatment and } \\
\text { observation indicators }\end{array}$ & Outcome indicator \\
\hline Provinces & Gender & Neonatal blood group & Operation (8 species) & Discharge weight \\
\hline Name of hospital & Date of birth & $\begin{array}{l}\text { Routine blood index (10 } \\
\text { times test) } \\
\text { (RBC/HB/HCT/WBC/PLT) }\end{array}$ & $\begin{array}{l}\text { Resuscitation Methods in } \\
\text { Delivery Room ( } 9 \text { species) }\end{array}$ & Hospitalization days (days) \\
\hline Age & $\begin{array}{l}\text { Date of } \\
\text { admission }\end{array}$ & $\begin{array}{l}\text { Liver function index (5 } \\
\text { times test) } \\
\text { (TBIL/DBIL/ALT/TP) }\end{array}$ & $\begin{array}{l}\text { Ventilator application } \\
\text { (Yes/No) }\end{array}$ & Hospitalization expenses \\
\hline $\begin{array}{l}\text { Mode of delivery } \\
\text { (Natural delivery/ } \\
\text { Midwifery/Cesarean } \\
\text { section) }\end{array}$ & $\begin{array}{l}\text { Date of } \\
\text { discharge }\end{array}$ & $\begin{array}{l}\text { Coagulation index } \\
\text { (5times test) } \\
\text { (APTT/PT/INR/FIB) }\end{array}$ & $\begin{array}{l}\text { Postpartum umbilical cord } \\
\text { clipping time(0-30s/1- } \\
60 \mathrm{~s} / 1- \\
2 \mathrm{~min} / 2 \mathrm{~min} / \text { unknow) }\end{array}$ & Days in NICU (days) \\
\hline $\begin{array}{l}\text { Number of births } \\
(1 / \geq 2)\end{array}$ & Birth weight & $\begin{array}{l}\text { Blood gas index (10 times } \\
\text { test) } \\
\text { (PH/P02/PCO2/LAC) }\end{array}$ & $\begin{array}{l}\text { Blood transfusion } \\
\text { treatmen } \mathrm{t}( \\
\text { time/volume/type(15 } \\
\text { blood products) })\end{array}$ & $\begin{array}{l}\text { Main diagnosis of discharge } \\
\text { (14 species) }\end{array}$ \\
\hline $\begin{array}{l}\text { Pregnancy times } \\
(1 / 2 / \geq 3)\end{array}$ & Birth length & & $\begin{array}{l}\text { Adverse events of blood } \\
\text { transfusion (8 species) }\end{array}$ & $\begin{array}{l}\text { Outcome (cure and } \\
\text { improvement/transfers/death) }\end{array}$ \\
\hline Parity $(1 / 2 / \geq 3)$ & $\begin{array}{l}\text { Birth head } \\
\text { circumference }\end{array}$ & & $\begin{array}{l}\text { Adverse events of blood } \\
\text { transfusion (8 species) }\end{array}$ & Complications (12 species) \\
\hline \multirow[t]{3}{*}{$\begin{array}{l}\text { Maternal complication } \\
\text { (11 species) }\end{array}$} & $\begin{array}{l}\text { Admission } \\
\text { weight }\end{array}$ & & $\begin{array}{l}\text { Evaluation of curative } \\
\text { effect after blood } \\
\text { transfusion( } 4 \text { species) }\end{array}$ & Causes of death (9 species) \\
\hline & $\begin{array}{l}\text { Agpar score (1-5- } \\
\text { 10) }\end{array}$ & & $\begin{array}{l}\text { Evaluation of curative } \\
\text { effect after blood } \\
\text { transfusion( } 4 \text { species) }\end{array}$ & $\begin{array}{l}\text { Follow-up after discharge } \\
(1 \mathrm{~W} / 1 \mathrm{M} / 3 \mathrm{Y})\end{array}$ \\
\hline & $\begin{array}{l}\text { Neonatal } \\
\text { Admission } \\
\text { Accompanying } \\
\text { Diseases } \\
\text { (15 species) }\end{array}$ & & 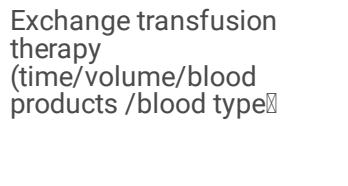 & Bailey scale \\
\hline
\end{tabular}

Maternal complication (11 species) = 1 no 2 respiratory system disease 3 circulatory system disease 4 digestive system disease 5 blood disease 6 childbirth disease 7 reproductive system infection 8 Maternal and infant blood type incompatibility 9 uterine disease 10 placental comorbidities 11 other diseases. Neonatal Admission Accompanying Diseases $(15$ species $)=1$ premature infant 2 low birth weight infant 3 sepsis 4 neonatal necrotizing colitis 5 neonatal bleeding 6 neonatal hemolysis 7 neonatal hyperbilirubinemia (non-immune factor) 8 neonatal anemia 9 thrombocytopenia 10 neonatal disseminated intravascular bleeding 11 neonatal pneumonia 12 birth asphyxia 13 neonatal bronchopulmonary dysplasia 14 neonatal respiratory distress syndrome 15 other neonatal diseases. Operation (8species) $=1$ no 2 PICC 3 umbilical vein catheterization 4 blood exchange 5 lumbar puncture 6 blue light irradiation 7 cardiovascular surgery 8 other operations. Resuscitation Methods in Delivery Room ( 9 species) $=1$ normobaric oxygen therapy 2 balloon pressurized oxygen therapy 3 endotracheal intubation balloon pressurized oxygen therapy 4 chest compressions 5 trachea cannula 6 epinephrine 7 volume expansion 8 naloxone 9 unknown. Type(15 blood products) $=1$ red blood cell (leukocyte-filtered, irradiated) 2 red blood cell (non-leukocyte-filtered, irradiated) 3 red blood cell (nonleukocyte-filtered, nonirradiated) 4 red blood cell (irradiated) 5 red blood cells (leukocyte-filtered) 6 fresh frozen plasma 7 fresh frozen plasma (virus inactivated) 8 frozen plasma 9 apheresis platelets (leukocyte-filtered) 10 apheresis platelets (non-leukocyte-filtered) 11 cryoprecipitate 12 whole blood 13 CMV antibody testing of blood products (positive) 14 CMVantibody testing of blood products (negative) $15 \mathrm{CMV}$ antibody testing of blood products (unknown). Adverse events of blood transfusion ( 8 species) $=1$ hemolysis reaction 2 coagulation dysfunction 3 circulation overload 4 metabolic disorder 5 acute necrotizing enterocolitis 6 hypothermia 7 hypocalcemia 8 acute lung injury. Evaluation of curative effect after blood transfusion( 4 species) $=$ color of skin, mental state, feeding, heart rate reduction( 1 obvious, 2 improved, 3 normal, 4 no change). Main diagnosis of discharge (14 species)=1 premature infant 2 low birth weight infant 3 sepsis 4 neonatal necrotizing colitis 5 neonatal bleeding 6 neonatal hemolysis 7 neonatal hyperbilirubinemia (non-immune factor) 8 thrombocytopenia 9 neonatal disseminated intravascular bleeding 10 neonatal pneumonia 11 neonatal asphyxia 12 neonatal bronchopulmonary dysplasia 
13 neonatal respiratory distress syndrome 14 other neonatal diseases. Complications ( 12 species $)=1$ none 2 retinopathy of prematurity 3 acute necrotizing enterocolitis 4 chronic bronchopulmonary dysplasia 5 intracranial hemorrhage 6 neonatal periventricular leukomalacia 7 cholestasis syndrome 8 hepatitis 9 neurodevelopmental disorder 10 neonatal encephalopathy 11 coagulation dysfunction 12 others. Causes of death ( 9 species) $=1$ sepsis 2 pulmonary hemorrhage 3 pneumonia 4 respiratory distress syndrome 5 asphyxia 6 bronchopulmonary dysplasia 7 hypoxic ischemic encephalopathy 8 neonatal necrotizing enterocolitis 9 others.

Table 2 Basic demographic characteristics of mothers in the neonatal blood transfusion cohort

\begin{tabular}{|c|c|c|c|c|c|c|c|c|c|c|}
\hline & & \multicolumn{3}{|l|}{$<1500 \mathrm{~g}$} & \multicolumn{3}{|c|}{$1500-2500 \mathrm{~g}$} & \multicolumn{3}{|c|}{$\geq 2500 \mathrm{~g}$} \\
\hline & & 0 & 1 & $\mathbf{P}$ & 0 & 1 & $\mathbf{P}$ & 0 & 1 & $\mathbf{P}$ \\
\hline Total (n) & & 674 & 643 & & 1104 & 297 & & 1025 & 178 & \\
\hline Age & & $\begin{array}{l}30(19- \\
44)\end{array}$ & $\begin{array}{l}30(18- \\
42)\end{array}$ & 0.194 & $\begin{array}{l}30(16- \\
45)\end{array}$ & $\begin{array}{l}30(18- \\
47)\end{array}$ & 0.659 & $\begin{array}{l}30(17- \\
44)\end{array}$ & $\begin{array}{l}30(14- \\
44)\end{array}$ & 0.658 \\
\hline \multirow[t]{4}{*}{ Mode of delivery } & $\begin{array}{l}\text { Natural } \\
\text { delivery }\end{array}$ & 110 & 471 & \multirow[t]{4}{*}{0.755} & 345 & 111 & \multirow[t]{4}{*}{0.076} & 443 & 77 & \multirow[t]{4}{*}{0.486} \\
\hline & Midwifery & 4 & 8 & & 12 & 5 & & 21 & 4 & \\
\hline & $\begin{array}{l}\text { Cesarean } \\
\text { section }\end{array}$ & 148 & 574 & & 747 & 181 & & 560 & 97 & \\
\hline & Unknown & 1 & 1 & & 0 & 0 & & 1 & 0 & \\
\hline \multirow[t]{3}{*}{ Number of births } & Single fetus & 166 & 734 & \multirow[t]{3}{*}{0.062} & 771 & 215 & \multirow[t]{3}{*}{0.324} & 962 & 164 & \multirow[t]{3}{*}{0.773} \\
\hline & Multiple births & 92 & 309 & & 321 & 78 & & 48 & 7 & \\
\hline & Unknown & 5 & 11 & & 12 & 4 & & 15 & 7 & \\
\hline \multirow[t]{4}{*}{ Pregnancy times } & 1 & 68 & 387 & \multirow[t]{4}{*}{0.012} & 375 & 107 & \multirow[t]{4}{*}{0.312} & 345 & 64 & \multirow[t]{4}{*}{0.640} \\
\hline & 2 & 85 & 302 & & 304 & 90 & & 331 & 55 & \\
\hline & $\begin{array}{l}3 \text { times or } \\
\text { more }\end{array}$ & 94 & 318 & & 374 & 92 & & 332 & 54 & \\
\hline & Unknown & 16 & 47 & & 51 & 8 & & 17 & 5 & \\
\hline \multirow[t]{4}{*}{ Parity } & 1 & 112 & 484 & \multirow[t]{4}{*}{0.282} & 447 & 143 & \multirow[t]{4}{*}{0.065} & 474 & 89 & \multirow[t]{4}{*}{0.600} \\
\hline & 2 & 121 & 450 & & 522 & 119 & & 462 & 66 & \\
\hline & $\begin{array}{l}3 \text { times or } \\
\text { more }\end{array}$ & 21 & 77 & & 96 & 28 & & 71 & 18 & \\
\hline & Unknown & 9 & 43 & & 39 & 7 & & 18 & 5 & \\
\hline $\begin{array}{l}\text { Number of mothers with } \\
\text { complications }(n)\end{array}$ & & 117 & 453 & 0.009 & 401 & 118 & 0.944 & 276 & 39 & 0.149 \\
\hline
\end{tabular}

Table 3 Basic demographic characteristics of newborns in the neonatal blood transfusion cohort 


\begin{tabular}{|c|c|c|c|c|c|c|c|c|c|c|}
\hline & & \multicolumn{3}{|l|}{$<1500 \mathrm{~g}$} & \multicolumn{3}{|l|}{$1500-2500 \mathrm{~g}$} & \multicolumn{3}{|l|}{$\geq 2500 \mathrm{~g}$} \\
\hline & & 0 & 1 & $\mathbf{P}$ & 0 & 1 & $\mathbf{P}$ & 0 & 1 & $\mathbf{P}$ \\
\hline Total (n) & & 263 & 1054 & & 1104 & 297 & & 1025 & 178 & \\
\hline \multirow[t]{2}{*}{ Gender } & Male & 148 & 552 & \multirow[t]{2}{*}{0.257} & 626 & 189 & \multirow[t]{2}{*}{0.032} & 610 & 107 & \multirow[t]{2}{*}{0.892} \\
\hline & Female & 115 & 502 & & 478 & 108 & & 415 & 71 & \\
\hline $\begin{array}{l}\text { Birth weight } \\
M(\max , \min )\end{array}$ & & $\begin{array}{l}1235(530- \\
1490)\end{array}$ & $\begin{array}{l}1226(630- \\
1498)\end{array}$ & 0.817 & $\begin{array}{l}1813 \\
(1500- \\
2480)\end{array}$ & $\begin{array}{l}1760 \\
(1500- \\
2490)\end{array}$ & 0.147 & $\begin{array}{l}3025 \\
(2500- \\
5500)\end{array}$ & $\begin{array}{l}3175 \\
(2500- \\
8600)\end{array}$ & 0.002 \\
\hline Birth length & & $38(27-54)$ & $38(29-53)$ & 0.486 & $43(28-60)$ & $43(32-53)$ & 0.017 & $50(32-57)$ & $50(42-56)$ & 0.044 \\
\hline \multicolumn{11}{|l|}{$M(\max , \min )$} \\
\hline Head circumference & & $28(21-47)$ & $28(18-40)$ & 0.992 & $30(21-41)$ & $30(21-49)$ & 0.766 & $34(23-48)$ & $34(31-44)$ & 0.043 \\
\hline \multicolumn{11}{|l|}{$M(\max , \min )$} \\
\hline Admission weight & & 1265 & 1250 & 0.684 & 1870 & 1750 & 0.001 & 3040 & 3100 & 0.291 \\
\hline \multicolumn{11}{|l|}{ M } \\
\hline \multirow[t]{3}{*}{ Agpar score (M) } & $1 \mathrm{~min}$ & 8 & 8 & 0.179 & 9 & 8 & 0.084 & 9 & 9 & 0.007 \\
\hline & $5 \mathrm{~min}$ & 9 & 9 & 0.005 & 9 & 9 & 0.050 & 10 & 9 & 0.012 \\
\hline & $10 \mathrm{~min}$ & 10 & 9 & 0.023 & 10 & 10 & 0.192 & 10 & 10 & 0.010 \\
\hline \multicolumn{2}{|c|}{$\begin{array}{l}\text { Total number of diseases } \\
\text { associated } M(\max , \min )\end{array}$} & $4(0-10)$ & $4(0-11)$ & 0.414 & $4(0-14)$ & $4(0-12)$ & 0.149 & $2(0-8)$ & $2(0-6)$ & 0.531 \\
\hline \multicolumn{2}{|c|}{$\begin{array}{l}\text { Number of cases of ventilator } \\
\text { application } \mathrm{n}(\%)\end{array}$} & $\begin{array}{l}219 \\
(83.27)\end{array}$ & $\begin{array}{l}720 \\
(68.31)\end{array}$ & 0.000 & $571(51.72)$ & $177(59.60)$ & 0.033 & $\begin{array}{l}285 \\
(27.83)\end{array}$ & $74(41.34)$ & 0.000 \\
\hline
\end{tabular}

Table 4 Treatment of blood transfusion by restricted blood transfusion and non-restricted blood transfusion

\begin{tabular}{|c|c|c|c|c|c|c|c|c|c|c|}
\hline & & \multicolumn{3}{|l|}{$<1500 \mathrm{~g}$} & \multicolumn{3}{|c|}{$1500-2500 \mathrm{~g}$} & \multicolumn{3}{|c|}{$\geq 2500 \mathrm{~g}$} \\
\hline & & 0 & 1 & $\mathbf{P}$ & 0 & 1 & $\mathbf{P}$ & 0 & 1 & $\mathbf{P}$ \\
\hline \multirow[t]{3}{*}{ Hb level } & Admissions (M) & 109 & 157 & 0.000 & 133 & 165 & 0.000 & 110 & 159 & 0.000 \\
\hline & Minimum during hospitalization (M) & 82 & 95 & 0.000 & 94 & 111 & 0.000 & 94 & 121 & 0.000 \\
\hline & Discharge(M) & 111 & 117 & 0.150 & 116 & 126 & 0.000 & 121 & 134 & 0.000 \\
\hline \multirow{4}{*}{$\begin{array}{l}\text { Red blood cell } \\
\text { infusion }\end{array}$} & Number of infusions $(M)$ & 2 & 2 & 0.000 & 1 & 1 & 0.351 & 1 & 1 & 0.798 \\
\hline & Average total infusion volume $(\mathrm{mL})$ & 60 & 50 & 0.000 & 46 & 44 & 0.147 & 60 & 60 & 0.131 \\
\hline & $\begin{array}{l}\text { Average infusion volume per } \\
\text { infusion }(\mathrm{mL})\end{array}$ & 26 & 27 & 0.843 & 35 & 31 & 0.000 & 50 & 50 & 0.015 \\
\hline & $\begin{array}{l}\text { Mean infusion per kilogram of body } \\
\text { weight (mL) }\end{array}$ & 10 & 10 & 0.867 & 9 & 9 & 0.064 & 8 & 8 & 0.239 \\
\hline \multirow[t]{5}{*}{ Plasma infusion } & Number of infusion cases (\%) & $\begin{array}{l}53 \\
(20.15)\end{array}$ & $\begin{array}{l}289 \\
(27.42)\end{array}$ & & $\begin{array}{l}126 \\
(11.41)\end{array}$ & $\begin{array}{l}143 \\
(48.15)\end{array}$ & & $\begin{array}{l}140 \\
(13.66)\end{array}$ & $\begin{array}{l}56 \\
(31.46)\end{array}$ & \\
\hline & Number of infusions (M) & 1 & 2 & 0.113 & 1 & 2 & 0.039 & 1 & 2 & 0.200 \\
\hline & Average total infusion volume $(\mathrm{mL})$ & 30 & 34 & 0.998 & 47 & 57 & 0.146 & 71 & 93 & 0.023 \\
\hline & $\begin{array}{l}\text { Average infusion volume per } \\
\text { infusion }(\mathrm{mL})\end{array}$ & 20 & 20 & 0.053 & 30 & 28 & 0.142 & 50 & 50 & 0.051 \\
\hline & $\begin{array}{l}\text { Mean infusion per kilogram of body } \\
\text { weight (mL) }\end{array}$ & 9 & 8 & 0.022 & 8 & 8 & 0.803 & 7 & 8 & 0.240 \\
\hline \multirow[t]{5}{*}{ Plt infusion } & Number of infusion cases (\%) & $\begin{array}{l}13 \\
(4.94)\end{array}$ & $\begin{array}{l}35 \\
(3.32)\end{array}$ & & $\begin{array}{l}24 \\
(2.17)\end{array}$ & $\begin{array}{l}12 \\
(4.04)\end{array}$ & & $\begin{array}{l}30 \\
(2.93)\end{array}$ & $\begin{array}{l}9 \\
(5.06)\end{array}$ & \\
\hline & Number of infusions (M) & 1 & 1 & 0.161 & 1 & 1 & 0.577 & 1 & 1 & 0.805 \\
\hline & Average total infusion volume $(\mathrm{mL})$ & 28 & 23 & 0.388 & 40 & 38 & 0.987 & 60 & 80 & 0.429 \\
\hline & $\begin{array}{l}\text { Average infusion volume per } \\
\text { infusion }(\mathrm{mL})\end{array}$ & 20 & 20 & 0.809 & 35 & 31 & 0.688 & 58 & 50 & 0.582 \\
\hline & $\begin{array}{l}\text { Mean infusion per kilogram of body } \\
\text { weight (mL) }\end{array}$ & 9 & 9 & 0.971 & 10 & 9 & 0.945 & 9 & 8 & 0.756 \\
\hline
\end{tabular}


Table 5 Analysis of main outcome indicators of neonatal blood transfusion

\begin{tabular}{|c|c|c|c|c|c|c|c|c|c|c|c|c|c|c|c|c|}
\hline & & \multicolumn{6}{|c|}{$<1500 \mathrm{~g}$} & \multicolumn{6}{|c|}{$1500-2500 \mathrm{~g}$} & \multicolumn{3}{|c|}{$\geq 2500 \mathrm{~g}$} \\
\hline & & 0 & 1 & OR & $\mathrm{Cl}$ & & $\mathbf{P}$ & 0 & 1 & OR & $\mathrm{Cl}$ & & $\mathbf{P}$ & 0 & 1 & c \\
\hline \multicolumn{2}{|c|}{ Total number (n) } & 263 & 1054 & & & & & 1104 & 297 & & & & & 1025 & 178 & \\
\hline \multirow[t]{3}{*}{ Death } & $\begin{array}{l}\text { Total } \\
\text { N (\%) }\end{array}$ & $\begin{array}{l}30 \\
(11.41)\end{array}$ & $\begin{array}{l}54 \\
(5.12)\end{array}$ & 0.416 & 0.260 & 0.666 & $\begin{array}{l}<.05 \\
0.05\end{array}$ & $\begin{array}{l}39 \\
(3.53)\end{array}$ & $\begin{array}{l}14 \\
(4.71)\end{array}$ & 1.374 & 0.735 & 2.569 & $\begin{array}{l}> \\
0.05\end{array}$ & $\begin{array}{l}31 \\
(3.02)\end{array}$ & $\begin{array}{l}17 \\
(9.55)\end{array}$ & 3 \\
\hline & $\begin{array}{l}\text { During } \\
\text { hospitalization } \\
\text { N (\%) }\end{array}$ & $\begin{array}{l}11 \\
(4.18)\end{array}$ & $\begin{array}{l}25 \\
(2.37)\end{array}$ & & & & & $\begin{array}{l}8 \\
(0.72)\end{array}$ & $\begin{array}{l}5 \\
(1.68)\end{array}$ & & & & & $\begin{array}{l}9 \\
(0.88)\end{array}$ & $\begin{array}{l}6 \\
(3.37)\end{array}$ & \\
\hline & $\begin{array}{l}\text { Follow-up for } \\
1 \text { week } \\
N(\%)\end{array}$ & $\begin{array}{l}15 \\
(5.7)\end{array}$ & $\begin{array}{l}22 \\
(8.37)\end{array}$ & & & & & $\begin{array}{l}20 \\
(1.81)\end{array}$ & $\begin{array}{l}7 \\
(2.36)\end{array}$ & & & & & $\begin{array}{l}17 \\
(1.66)\end{array}$ & $\begin{array}{l}8 \\
(4.49)\end{array}$ & \\
\hline & $\begin{array}{l}\text { Follow-up for } \\
1 \text { month } \\
N(\%)\end{array}$ & $\begin{array}{l}4 \\
(1.52)\end{array}$ & $\begin{array}{l}7 \\
(2.66)\end{array}$ & & & & & $\begin{array}{l}11 \\
(1.00)\end{array}$ & $\begin{array}{l}2 \\
(0.67)\end{array}$ & & & & & $\begin{array}{l}5 \\
(0.49)\end{array}$ & $\begin{array}{l}3 \\
(1.69)\end{array}$ & \\
\hline
\end{tabular}

Table 6 Analysis of secondary outcome indicators of neonatal blood transfusion

\begin{tabular}{|c|c|c|c|c|c|c|c|c|c|}
\hline & \multicolumn{3}{|c|}{$<1500 \mathrm{~g}$} & \multicolumn{3}{|c|}{$1500-2500 \mathrm{~g}$} & \multicolumn{3}{|c|}{$\geq 2500 \mathrm{~g}$} \\
\hline & 0 & 1 & $\mathbf{P}$ & 0 & 1 & $\mathbf{P}$ & 0 & 1 & $\mathbf{P}$ \\
\hline Hospitalization days (M) & 38 & 40 & 0.074 & 22 & 26 & 0.002 & 10 & 14 & 0.000 \\
\hline NICU hospitalization days (M) & 30 & 29 & 0.547 & 9 & 16 & 0.000 & 0 & 0 & 0.186 \\
\hline Hospitalization expenses (Yuan, M) & 53954 & 68573 & 0.000 & 36727 & 51365 & 0.000 & 17891 & 22959 & 0.022 \\
\hline Number of complicated diseases in hospital (M) & 1 & 1 & 0.217 & 1 & 1 & 0.121 & 1 & 1 & 0.712 \\
\hline
\end{tabular}

\section{Figures}




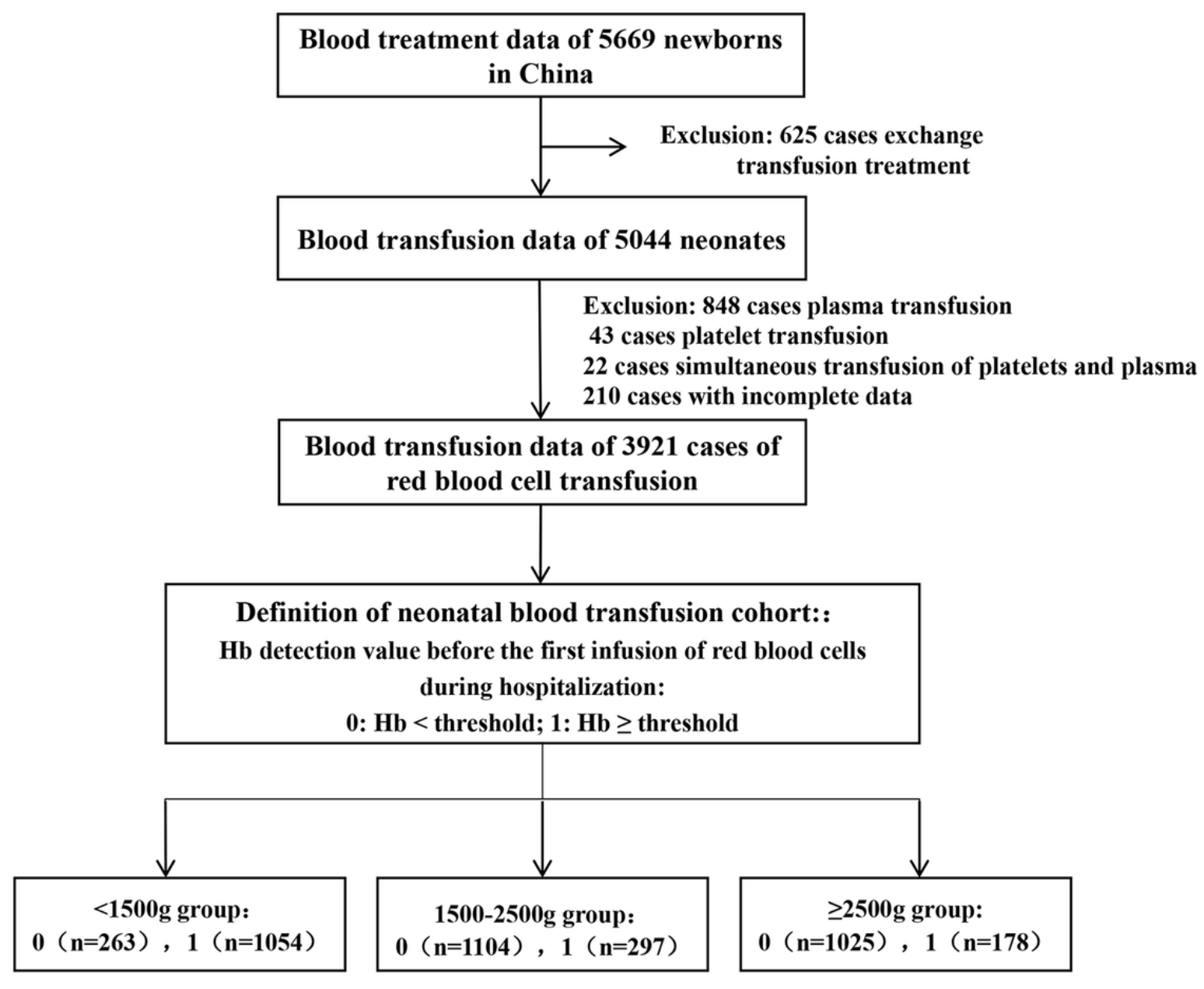

Figure 1

A unified spreadsheet was used to collect data in Forty-six hospitals covering 21 provinces and cities (Beijing, Gansu, Guangdong, Guangxi, Guizhou, Hebei, Henan, Heilongjiang, Hubei, Jilin, Jiangxi, Liaoning, Inner Mongolia, Shandong, Shanxi, Shaanxi, Sichuan, Xinjiang, Yunnan, Zhejiang, Chongqing, shown in Fig. 1). 


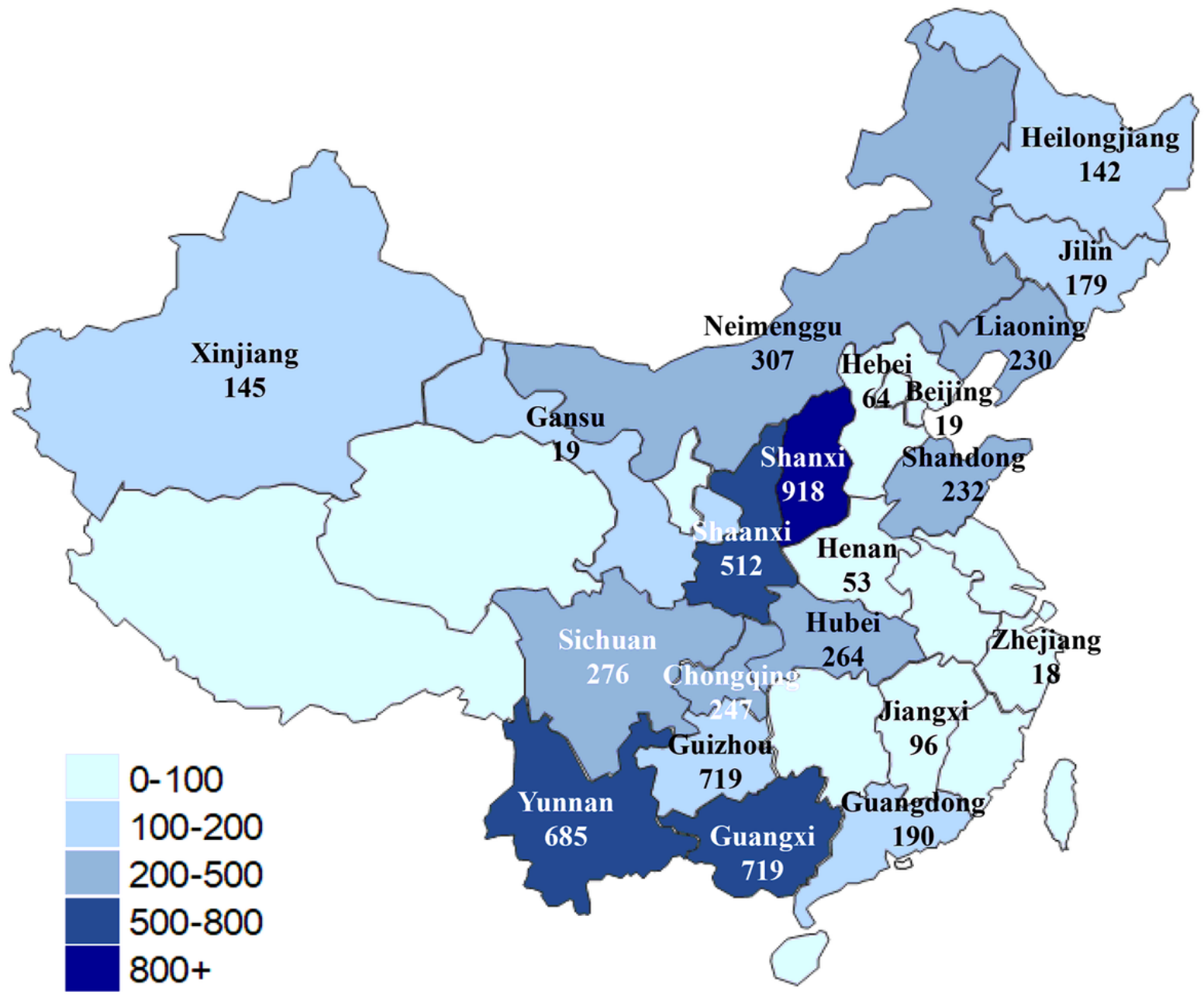

Figure 2

Among 5669 newborns with blood transfusion, 625 newborns with exchange transfusion treatment, 848 newborns with simple plasma transfusion, 43 newborns with simple platelet transfusion, 22 newborns with simultaneous platelet and plasma transfusion and 210 newborns with incomplete data were excluded, and 1.8 million data of 3921 newborns with red blood cell transfusion were analyzed (shown in Fig. 2).

\section{Supplementary Files}

This is a list of supplementary files associated with this preprint. Click to download.

- SupplementaryFigure1.tif 